\title{
Non-healing arm wound with a discharging sinus in an elderly patient with diabetes
}

\author{
Shaifali Bansal, Sushil Jindal, Rakesh Biswas \\ Department of Medicine, People's College of Medical Sciences and Research Centre, Bhopal, India
}

Correspondence to Shaifali Bansal, drshaifalibansal@gmail.com

\section{DESCRIPTION}

A 70-year-old male with diabetes presented to the surgical outpatient department with an abscess like a soft tissue swelling on his right upper arm. An incision and drainage procedure (I\&D) was carried out on an outpatient basis. The serous fluid thus obtained was sent for culture and sensitivity. The culture report showed sterile material. Following I\&D, the patient developed a non-healing wound producing copious serous discharge which did not respond to various systemic and local antibiotics (figures 1 and 2).

The patient also complained of pain in the right shoulder which was aggravated by movement. This was initially considered to be frozen shoulder, which is more common in people with diabetes.

A month later a bone deep sinus was found in the wound and a sonogram was ordered. The sinogram showed a sinus track going up into shoulder joint (figure 3). Exudate was stained for acid-fast bacteria (AFB) but was negative. According to Berney et al, synovial fluid smear stained for AFB is positive only in $27 \%$ of patients with tuberculous joints; $10^{4} \mathrm{AFB} / \mathrm{ml}$ is required for a result to be considered positive. Soft tissue swelling along with sinuses and cold abscesses are common in tuberculous arthritis. ${ }^{1}$

Hence, a provisional diagnosis of tuberculous arthritis of the right shoulder with tuberculous sinus extending to the upper arm was made. The patient was given a therapeutic trial of antitubercular drugs.

Within a month, discharge from sinus had subsided and 3 months later the wound had healed completely (figure 4). The patient also reported marked improvement in shoulder arthritis.

Tuberculous mono-arthritis involving the hip and knee is frequently reported in the literature, but there are very few reports of tuberculous shoulder. The incidence of tuberculosis of the shoulder joint is $1-2.8 \%$ of skeletal tuberculosis. ${ }^{2}$ In most cases of tuberculous disease of the shoulder, an abscess may eventually occur. It may track down as a sinus to dependent parts and open up in the arm or chest. In a case reported by Panas, the sinus came to the surface below the elbow. ${ }^{3}$ Infection should be suspected early when arthritis affects a single joint, as tuberculous arthritis may destroy a

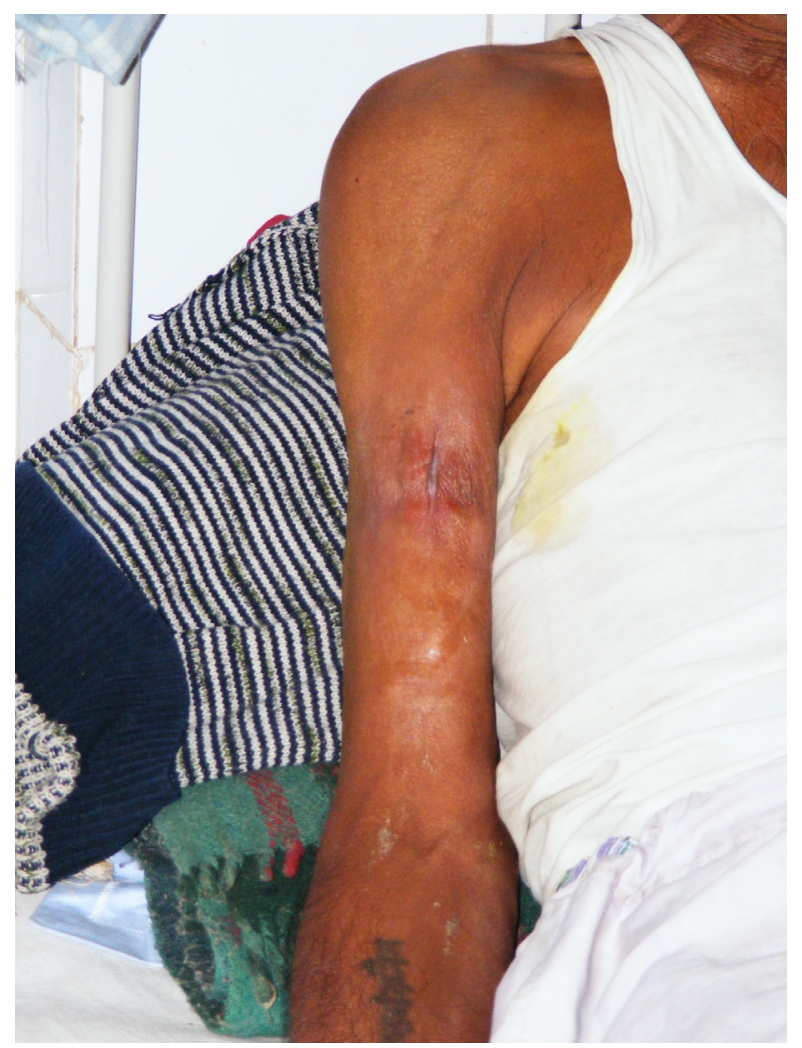

Figure 1 Wound in upper arm.

joint if left untreated. The presence of an underlying debilitating condition such as diabetes mellitus, as in our case, can predispose to tuberculous arthritis. ${ }^{4}$

Tuberculous arthritis should be considered when a single joint is involved in a patient with an underlying debilitating condition such as diabetes mellitus.

Competing interests None.

Patient consent Obtained. 


\section{BMJ Case Reports}

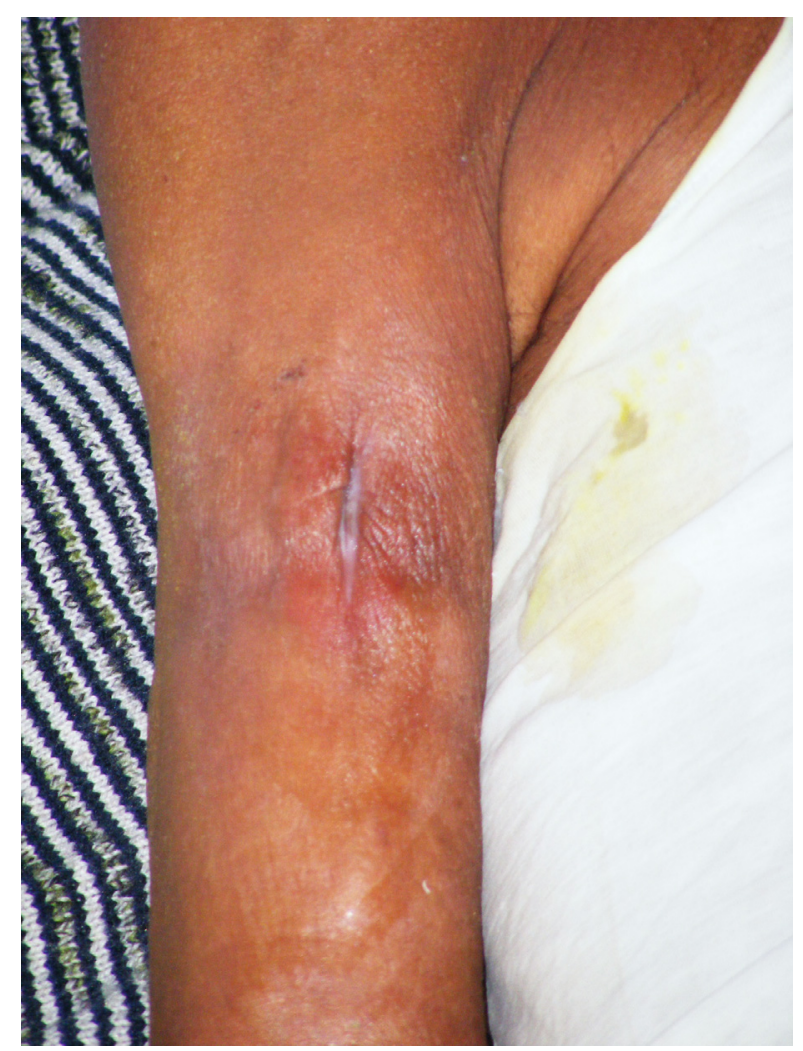

Figure 2 Discharging sinus.

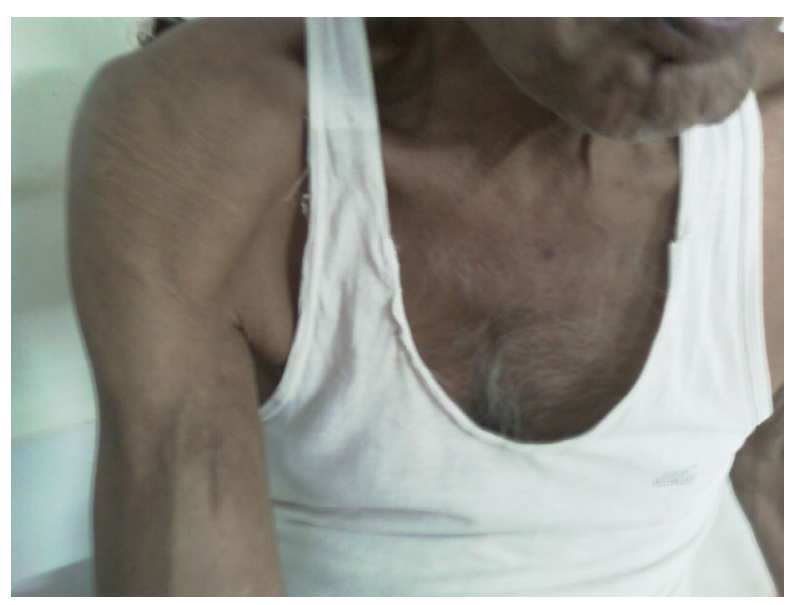

Figure 4 Healed lesion.

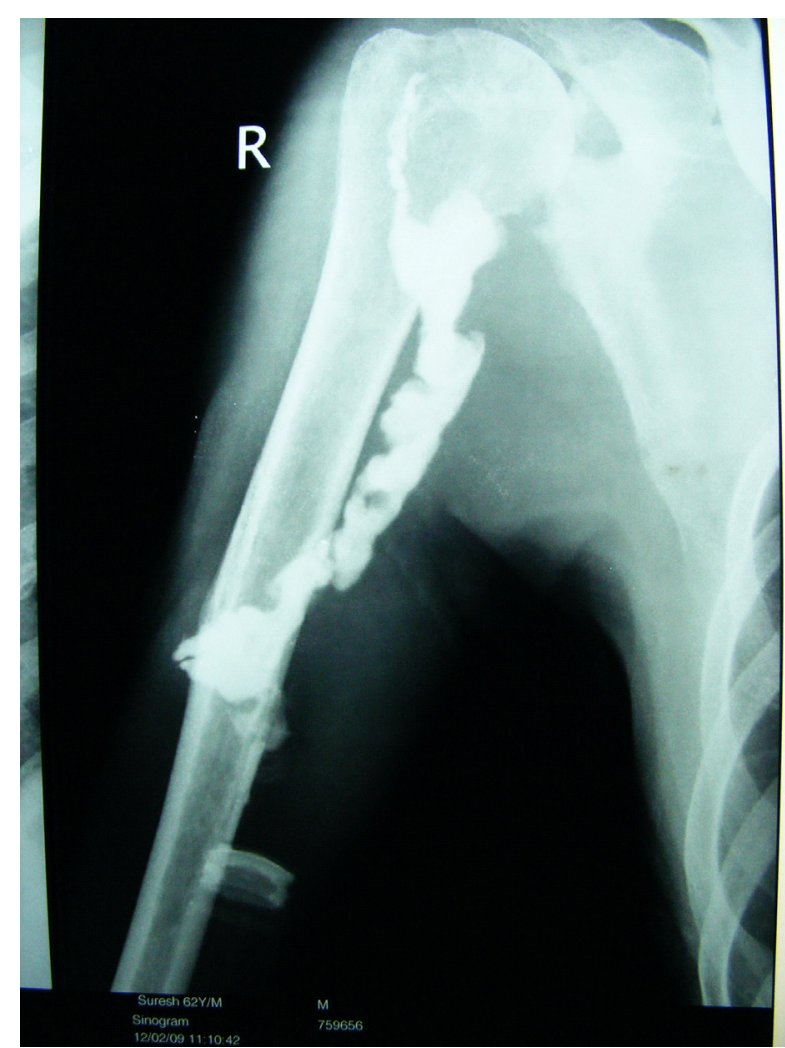

Figure 3 Sinogram.

\section{REFERENCES}

1. Berney S, Goldstein M, Beskho F. Clinical and Diagnostic features of Tuberculous. Arthritis Am J Med 1972;53:36-42.

2. Mangwani J, Gupta AK, Yadav CS, et al. Unusual presentation of shoulder joint tuberculosis: A case report. J Orthop Surg 2001;9:57-60.

3. Townsend WR. Tubercular Disease of the Shoulder-Joint. J Bone Joint Surg Am 1895;s1-7:137-58.

4. Davidson PT, Horowitz I. Skeletal Tuberculosis - A review with patient presentation and discussion. Am J Med 1970;48:77-84. 


\section{BMJ Case Reports}

This pdf has been created automatically from the final edited text and images.

Copyright 2010 BMJ Publishing Group. All rights reserved. For permission to reuse any of this content visit http://group.bmj.com/group/rights-licensing/permissions.

BMJ Case Report Fellows may re-use this article for personal use and teaching without any further permission.

Please cite this article as follows (you will need to access the article online to obtain the date of publication).

Bansal S, Jindal S, Biswas R. Non-healing arm wound with a discharging sinus in an elderly patient with diabetes. BMJ Case Reports 2010; 10.1136/bcr.12.2009.2556, date of publication

Become a Fellow of BMJ Case Reports today and you can:

- Submit as many cases as you like

Enjoy fast sympathetic peer review and rapid publication of accepted articles

Access all the published articles

- Re-use any of the published material for personal use and teaching without further permission

For information on Institutional Fellowships contact consortiasales@bmjgroup.com

Visit casereports.bmj.com for more articles like this and to become a Fellow 